\title{
Islam In America
}

\author{
Jane I. Smith. \\ New York: Columbia University Press, 1999. 251 pages.
}

Written by a professor of Islamic Studies at Hartford Seminary in Connecticut, Islam in America introduces the history and practice of Islam in the United States. The book opens with an overview of the origins and historical development of Islam that for the most part is fair, although there is the odd error ("Throughout the centuries, the call to prayer has been sung..." Some of the figures mentioned in Chapter 2, "Contributors to the Development of Islam" also cause eyebrows to be raised: how much the secularist Mustafa Kemal contributed to the development of Islam is surely debatable.

Moving on to the American context (Chapter 3), the author starts her exploration of Islamic history in the US with the waves of immigration from Muslim lands that began in the middle and latter part of the nineteenth century. Pre-Columbian visits to these shores by Muslims are touched upon, but it is noted that this is a new area of scholarship. The issue of Muslim slaves brought by force from Africa is dealt with later, in the chapter on AfricanAmerican Islam.

The issues faced by the earliest immigrants are touched upon, and a brief history of Islam in several major centers is given. Accounts of minority groupings - Shia, Sufis, Ismailis, Druze, and Ahmadis - are also given. Whether all of these groupings are "truly Islamic" or not is a moot point, however, the fact that they are connected to or have roots in the Islamic tradition means that they are often included in studies of Islam, particularly studies written by western observers. While stating that the majority of Muslims in the US are either immigrants or African-Americans, the author notes that there are significant numbers of converts from other backgrounds too; mention is made of Anglos, Hispanics and Native Americans who have come to Islam.

The history of African-American Muslims in the US warrants a chapter to itself (Chapter 4). He gives a broad overview of the entire spectrum of the Black Muslim experience, from slave times through the advent of Noble Drew Ali and W.D. Fard through the Nation of Islam to Louis Farrakhan and Warith Deen Muhammad. Sectarian groups that may be regarded as being on the "fringe," such as the "Five Percenters," are also discussed.

The author then moves on (Chapter 5) to current issues of concern to the Muslim community, such as family and women's issues, women and work, 
and hijab. Women's role in the mosque, and whether women should even be there in the first place, is another debate that is covered. Marriage and divorce is a further area of concern, as the author explores the tensions that may arise when Muslims whose values are more "conservative" seek to form families in the "liberal" American context. The perennial questions of beating and polygamy also come up. The author's presentation is fair, as far from seeking to "sensationalize" these controversial matters, she reports moderate Muslim views on both issues (i.e., Islam does not allow wife-beating, and that polygamy is constrained by certain conditions). Issues surrounding various generations, from the elderly to young children, are also presented.

The next two chapters of the book focus on more public aspects of being Muslim. Chapter 6, ("Living a Muslim Life in American Society"), opens with a discussion on education, which covers Muslim concerns about public schools. The alternatives of Islamic schools and homeschooling, and initiatives in tertiary education and the production of educational materials, are also dealt with. The remainder of the chapter covers other areas of practical concern, namely economics, nutrition and health, holidays (both dealing with non-Islamic holidays and how to celebrate Eid in the American context), and Islamic "products" (books, audio-visuals, clothing, etc.). The final section outlines personal problems faced by Muslims and various initiatives aimed at solving them.

"The Public Practice of Islam" (Chapter 7) revisits the development of mosques in the US, describing how the community slowly moved from holding prayers in one another's homes to acquiring buildings to having their own mosques custom-built. The question of imams is also discussed, exploring the pros and cons of imams brought in from overseas versus "home-grown" imams. The recent development of Muslim "chaplains" in educational institutions, the military and the prison system is also explored in some detail. This leads into a discussion of dawah, and an overview of different $d a^{\prime}$ wah movements active in the US. Also covered are some issues faced by new converts and relations with people of other faiths, as well as efforts to provide places for worship in airports, etc. A synopsis of major Islamic organizations is also given, including some women's organizations, although this section contains the rather baffling statement that the "Torontobased Canadian Council of Muslim Women" is one of the organizations that is "work[ing] to promote the welfare of American Muslim women." (One rather thinks that a more apt title for the book might have been Islam in North America). 
The important issue of combating anti-Muslim prejudice is also covered, and attention is drawn to media stereotyping, in particular. The comment, "the American Muslim community is deeply concerned that antiIslamic feelings on the part of the general public are growing rather than abating, exacerbated by international incidents of violence carried out in the name of Islam and abetted by the unfortunate portrayal of Muslims and Islam in the media." This is even more resonant, of course, following the tragic events of September 11, 2001.

The final chapter, "Looking to the Future", (Chapter 8), presents issues of immediate concern which the Muslim community has to come to terms with and work out, such as authority, unity, leadership, women and politics. The book ends on a positive note, stating that Islam is here to stay and can no longer be regarded as "foreign" or "eastem." "Islam has become part of America and Muslims are a growing and vital segment of its population."

The appendices to the book include brief biographical sketches of notable figures on the American Muslim scene, a glossary of Arabic and Islamic terms used in the book, and an exhaustive list of resources for further study, including addresses of organizations throughout the US and a large selection of Islamic websites.

This book is a useful introduction both for students of religion and social studies, and also for the educated general reader. It may be recommended for teachers, social workers, politicians and other professionals who need to develop an understanding of what Islam is and what it means to its followers. Muslims who want to know more about the history of their community in America will also find it of interest. On the whole, it is an upbeat and positive book; the author appears sympathetic towards Muslims and frequently allows Muslims to "speak for themselves" by quoting them directly.

Huda Khattab Author and Translator Toronto, Canada 